\title{
A Study on Working Capital Management at EID Parry
}

\author{
Santhiya $\mathrm{S}^{1}$ | Malarkodi $\mathrm{K}^{1}$
}

${ }^{1}$ Department of Management, M. Kumarasamy College of Engineering, Karur, Tamilnadu,

To Cite this Article

Santhiya S and Malarkodi K, "A Study on Working Capital Management at EID Parry”, International Journal for Modern Trends in Science and Technology, Vol. 06, Issue 07, July 2020, pp.:37-41; https://doi.org/10.46501/IJMTST060706

\section{Article Info}

Received on 11-June-2020, Revised on 18-June-2020, Accepted on 21-June-2020, Published on 30-June-2020.

\section{ABSTRACT}

The working capital management has an important role for the firm's success or failure because of its effect on firm's performance and liquidity. A well designed and implemented working capital management is expected to contribute positively to the creation of a firm's value. "Working Capital" is the capital invested in different items of current assets needed for the business, viz, inventory, debtors, cash and other current assets such as loans \& advances to third parties. Those current assets are essential for smooth business operations and proper utilization of fixed assets. The study is descriptive in nature. The secondary data is used for this study and four years balance sheet. The Working Capital Turnover Ratio, Current Asset Turnover Ratio, Probability Ratio. It was concluded that the working capital is a vital role of an organization

\section{KEYWORDS: Working Capital Management, Working Capital Turnover Ratio, Trend Analysi}

Copyright (C) 2014-2020 International Journal for Modern Trends in Science and Technology

DOI: https://doi.org/10.46501/IJMTST060706

\section{INTRODUCTION}

In every business an absolute best possible level of working capital is to be maintained for the function of day to day remittances. Any business cannot become older in absence of adequate working level. Working capital should ample sufficient to hold out the present liabilities but should not be a large amount more than the true requirement. It should be ensured by the firm's management people that the return yield through the funds engrossed in structuring working capital is no fewer than the return earns from extra investment alternatives. Within the situation, when the financial resources are insufficient and as a resulting cost of capital is to be enlarged, management of working capital becomes constant more crucial and important due to its deep influence on liquidity and profitability of the business. The term 'Working Capital' may mean
Gross Working Capital or Net Working Capital. Gross Working Capital means Current Assets.Net Working Capital means Current Assets less Current Liabilities. Unless otherwise specified, Capital means Net Working Capital. As such, Working Capital Management refers to correct management of Current Assets and Current Liabilities.

Dong (2010) reported that the firms' profitability and liquidity are affected by working capital management in his analysis. Pooled data are selected for carrying out the research for the era of 2006-2008 for assessing the companies listed in stock market of Vietnam. He focused on the variables that include profitability, conversion cycle and its related elements and the relationship that exists between them. From his research it was found that the relationships among these variables are strongly negative. 
It was examined by Bose (2013) that the working capital management impacts on firms' profitability. It was found in the study that in the electric equipment sector source of the working capital management components widely vary. Kaur and Singh (2013) study examined that the efficiency and profitability can be managed through working capital management. Their findings were in support to the earlier studies that efficient management of working capital significantly impacts profitability. Also Kumar and Ramanan (2013) supported that there has been an impact of working capital management on profitability of manufacturing firms. They found a positive relationship between profitability and debtors' day and inventory days.

Akoto Richard K., Vitor Dadson A. and Angmor Peter L. (2013) closely study the relationship between working capital management policies and profitability of the thirteen listed manufacturing firms in Ghana. At the end of the study, a significantly negative relationship between profitability and accounts receivable days is found to exist. Profitability is significantly positively influenced by the firms cash conversion cycle (CCC), current assets ratio and current asset turnover. It is also suggested that managers can create value for the shareholders by creating incentives to reduce their accounts receivable to 30 days.

Joseph Jisha (2014) closely examines the study of working capital management in Ashok Leyland and points out that the liquidity and profitability position of the company is not satisfactory, and needed to be strengthened in order to be able to meet its obligations in time.

Madhavi K. (2014) makes an empirical study of the co-relation between liquidity position and profitability of the paper mills in Andhra Pradesh. It has been observed that inefficient working capital management makes a negative impact on profitability and liquidity position of the paper mills.

\section{METHODOLOGY}

Research is a systematic inquiry to describe, explain, predict, and control the observed phenomenon. Research involves inductive and deductive methods. Secondary data is data gathered from studies, surveys, or experiments that have been run by other people or for other research. Secondary data is used for data collection. Tools used for data analysis are Ratio Analysis, Trend Analysis.

\section{RESULTS}

\subsection{Working Capital Turnover Ratio}

The working capital turnover ratio measures how well a company is utilizing its working capital to support a given level of sales. Working capital is current assets minus current liabilities. A high turnover ratio indicates that management is being extremely efficient in using a firm's short-term assets and liabilities to support sales. Conversely, a low ratio indicates that a business is investing in too many accounts receivable and inventory assets to support its sales, which could eventually lead to an excessive amount of bad debts and obsolete inventory write-offs. Also referred to as net sales to working capital, work capital turnover shows the relationship between the funds used to finance a company's operations and the revenues a company generates as a result.

\begin{tabular}{|c|c|c|c|}
\hline Years & Sales (Rs) & $\begin{array}{c}\text { Working Capital } \\
\text { (Rs) }\end{array}$ & Ratio \\
\hline $2014-2015$ & 211578 & 35920 & 5.89 \\
\hline $2015-2016$ & 234768 & -46885 & -5 \\
\hline $2016-2017$ & 1212226 & 93360 & 12.98 \\
\hline $2017-2018$ & 334391 & -46765 & -7.15 \\
\hline
\end{tabular}

\section{Interpretation}

The above table shows the working capital turnover ratio for the period of four years. It was 5.89 in the year of $2014-2015$ and it is decreased in the next year to -5 during the year $2015-2016$ and then slowly the working capital turnover increased to 12.98 in the year of $2016-2017$. A high turnover ratio shows management is being very efficient in using a company short term assets and liabilities for supporting sales. In $2017-2018$ the turnover ratio decreased to -7.5 and the decrease in the turnover ratio indicates inefficient utilization of working capital during the period

\subsection{Gross Profit Ratio}

Gross Profit Ratio is also known as Gross Profit Margin ratio, it establishes a relationship between gross profit earned and net revenue generated from operations (net sales). Gross profit ratio is a profitability ratio which is expressed as a percentage hence it is multiplied by 100 . Net sales consider both Cash and Credit Sales; on the other hand, gross profit is calculated as Net Sales minus COGS. Gross profit ratio helps to 
ascertain optimum selling prices and improve the efficiency of trading activities. It also helps find out the lowest selling price of goods per unit to an extent that the business will not suffer a loss.

\begin{tabular}{|c|c|c|c|}
\hline Years & $\begin{array}{c}\text { Gross } \\
\text { Profit (Rs) }\end{array}$ & $\begin{array}{c}\text { Net sales } \\
\text { (Rs) }\end{array}$ & Ratio \\
\hline $\begin{array}{c}2014- \\
2015\end{array}$ & 1419164 & 195375 & 7.26 \\
\hline $\begin{array}{c}2015- \\
2016\end{array}$ & 238582 & 220637 & 1.08 \\
\hline $\begin{array}{c}2016- \\
2017\end{array}$ & 1466711 & 1201671 & 1.22 \\
\hline $\begin{array}{c}2017- \\
2018\end{array}$ & 1533150 & 311201 & 4.92 \\
\hline
\end{tabular}

\section{Interpretation}

The above table shows the gross profit ratio for the period of four years. The highest value is 7.26 during the year of $2014-2015$ and lowest value is 1.08 during the year of $2015-2016$. The profit ratio is an indicator of a company's financial health. The lower margin indicates a company is under - pricing and the higher margin indicates that the company can make profit on sales.

\subsection{Net Profit Ratio}

The net profit percentage is the ratio of after-tax profits to net sales. It reveals the remaining profit after all costs of production, administration, and financing have been deducted from sales, and income taxes recognized. As such, it is one of the best measures of the overall results of a firm, especially when combined with an evaluation of how well it is using its working capital. The measure is commonly reported on a trend line, to judge performance over time. It is also used to compare the results of a business with its competitors. Net profit is not an indicator of cash flows, since net profit incorporates a number of non-cash expenses, such as accrued expenses, amortization, and depreciation.

\begin{tabular}{|c|c|c|c|}
\hline Years & $\begin{array}{c}\text { Net Profit } \\
\text { (Rs) }\end{array}$ & Net Sales (Rs) & Ratio \\
\hline $2014-2015$ & 208167 & 195375 & 1.06 \\
\hline $2015-2016$ & 231044 & 220637 & 1.04 \\
\hline $2016-2017$ & 239796 & 1201671 & 0.19 \\
\hline $2017-2018$ & 1529173 & 311201 & 4.9 \\
\hline
\end{tabular}

\section{Interpretation}

The above table shows the net profit ratio for the period of four years. It was 1.06 in the year of 2014 -2015 and then in the year of $2015-2016$ it is
1.04 and then in the year of $2017-2018$ value of ratio is 4.9.Net profit ratio is useful to measure the overall profitability of the business. A high ratio indicates the efficient management of the affairs of business.

\subsection{Current Ratio}

The current ratio is a liquidity ratio that measures a company's ability to pay short-term obligations or those due within one year. It tells investors and analysts how a company can maximize the current assets on its balance sheet to satisfy its current debt and other payables. The current ratio is sometimes referred to as the "working capital" ratio and helps investors understand more about a company's ability to cover its short-term debt with its current assets. The current ratio is a financial ratio that shows the proportion of a company's current assets to its current liabilities. The current ratio is probably the best known and most often used of the liquidity ratios, which analysts and investors use to evaluate the firm's ability to pay its short-term debt obligations, such as accounts payable.

\begin{tabular}{|c|c|c|c|}
\hline Years & $\begin{array}{c}\text { Current } \\
\text { Assets (Rs) }\end{array}$ & $\begin{array}{c}\text { Current } \\
\text { Liabilities (Rs) }\end{array}$ & Ratio \\
\hline $2014-2015$ & 153204 & 179701 & 0.8 \\
\hline $2015-2016$ & 108830 & 155715 & 0.69 \\
\hline $2016-2017$ & 113262 & 138217 & 0.8 \\
\hline $2017-2018$ & 164378 & 211143 & 0.7 \\
\hline
\end{tabular}

\section{Interpretation}

The table shows the current ratio for the period of four years. It was 0.8 during the year 2014-2015 and then 0.69 in the year of $2015-2016$ and in the last year it is 0.7 during the year of 2017 2018. When the current ratio is high in the company then the company able to pay off its current liabilities using current assets.

\subsection{Current Asset Turnover Ratio}

Current Asset Turnover Ratio is an activity ratio measuring firm's ability of generating sales through its current assets (cash, inventory, accounts receivable, etc.). It can be calculated by dividing the firm's net sales by its average current assets, and it shows the number of turns made by the current assets of the enterprise. Current Assets Turnover Ratio indicates that the current assets are turned over in the form of sales more number of times. A high current assets turnover ratio indicates the capability of the organization to achieve maximum sales with the minimum investment in current assets. Higher the current ratio better will be the situation. 


\begin{tabular}{|c|c|c|c|}
\hline Years & Sales (Rs) & $\begin{array}{c}\text { Current } \\
\text { Assets (Rs) }\end{array}$ & Ratio \\
\hline $2014-2015$ & 195375 & 153204 & 1.27 \\
\hline $2015-2016$ & 220637 & 108830 & 2.02 \\
\hline $2016-2017$ & 1201671 & 113262 & 10.6 \\
\hline $2017-2018$ & 311201 & 164378 & 1.89 \\
\hline
\end{tabular}

\section{Interpretation}

The above table shows the current asset turnover ratio for the period of four years. It was 1.27 in the year of $2014-2015$ and then in the year of 2015 2016 the ratio value is 2.02 and in the next year the value of ratio increased by 10.6 in the year of 2016 - 2017.A high current asset turnover ratio indicates the capacity of the organization to achieve maximum sales with minimum investment in current assets. In the last year the value decreased by 1.89 .

\subsection{Fixed Asset Turnover Ratio}

Fixed Asset Turnover Ratio is an efficiency ratio that indicates how well or efficiently a business uses fixed assets to generate sales. This ratio divides net sales by net fixed assets, calculated over an annual period. The net fixed assets include the amount of property, plant, and equipment, less the accumulated depreciation. Generally, a higher fixed asset ratio implies more effective utilization of investments in fixed assets to generate revenue. This ratio is often analyzed alongside leverage and profitability ratios. The fixed asset balance is used as a net of accumulated depreciation. A higher fixed asset turnover ratio indicates that a company has effectively used investments in fixed assets to generate sales.

\section{Interpretation}

The above table shows the fixed asset turnover ratio for the period of four years. It was 1.53 during

\begin{tabular}{|c|c|c|c|}
\hline Years & $\begin{array}{c}\text { Total Sales } \\
\text { (Rs) }\end{array}$ & $\begin{array}{c}\text { Total Net fixed } \\
\text { Assets (Rs) }\end{array}$ & Ratio \\
\hline $2014-2015$ & 211578 & 137672 & 1.53 \\
\hline $2015-2016$ & 234768 & 131681 & 1.78 \\
\hline $2016-2017$ & 1212226 & 142107 & 8.5 \\
\hline $2017-2018$ & 334391 & 109852 & 3.04 \\
\hline
\end{tabular}

the year of $2014-2015$ and then in the year $2015-$ 2016 the ratio value is 1.78 and in the year of 2017 - 2018 the value of ratio is 8.5. A higher ratio implies that management is using its fixed assets more effectively. In the last year the ratio value is 3.04 during the year $2017-2018$.

\subsection{Trend Analysis of Current Asset}

Trend analysis is also known as Horizontal analysis is a financial statement analysis techniques that shows the changes in the amounts of corresponding financial statement items over a period of time. It is very useful tool to evaluate the trend situations.

\begin{tabular}{|c|c|c|}
\hline Years & Amount (Rs) & Trend (\%) \\
\hline $2014-2015$ & 153204 & 100 \\
\hline $2015-2016$ & 108830 & 71 \\
\hline $2016-2017$ & 113262 & 73 \\
\hline $2017-2018$ & 164378 & 107 \\
\hline
\end{tabular}

\section{Interpretation}

The above table shows that the trend analysis of current asset for the period of four years. It was $100 \%$ in the year of $2014-2015$ and the current asset increased to 107 in the year of $2017-2018$.

\subsection{Trend Analysis of Sales}

Sales trend analysis is the review of historical revenue results to detect patterns. Sales trend analysis is a useful budgeting and financial analysis method that can indicate the onset of changes in the near-term revenue growth rates of a business. It is rarely adequate to simply plot the total sales of a business on a trend line and expect to obtain any significant information from it. Most organizations sell many products to a variety of customers, and in many regions, which means that sales can be broken down into a number of sub-groups and then reviewed on a trend line.

\begin{tabular}{|c|c|c|}
\hline Years & Amount (Rs) & Trend (\%) \\
\hline $2014-2015$ & 211578 & 100 \\
\hline $2015-2016$ & 234768 & 110 \\
\hline $2016-2017$ & 1212226 & 572 \\
\hline $2017-2018$ & 334391 & 158 \\
\hline
\end{tabular}

\section{Interpretation}

The above table shows the trend analysis of sales for period of four years. It was $100 \%$ in the year of $2014-2015$ and the sales trend increased to $158 \%$ in the year of $2017-2018$.

\section{Discussion}

\section{Findings}

- The working capital ratio in the year 2014 2015 is 5.89 and in the final year it is decreased to -7.5 .

- Gross profit ratio in the year $2014-2015$ is 7.26 and then in the year of $2017-2018$ the value is decreased to 4.92 . 
- $\quad$ Net profit ratio in the year $2014-2015$ is 1.06 and then in the year 2017 - 2018 the ratio value is increased to 4.9 .

- Current ratio in the year 2014-2015 is 0.8 and then the ratio value is decreased to 0.7 in the year $2017-2018$.

- Current asset turnover ratio is 1.27 in the year $2014-2015$ and the value is increased in the year $2016-2017$ and ratio value is 10.6 .

- Fixed asset turnover ratio in the year 2015 2016 is lowest ratio and then the highest value is 8.5 in the year $2016-2017$.

- The trend analysis of current asset it was $100 \%$ in the year of 2014 - 2015 and the current asset increased to 107 in the year of $2017-2018$.

- The trend analysis of sales it was $100 \%$ in the year of 2014 - 2015 and the sales trend increased to $158 \%$ in the year of $2017-2018$.

\section{Suggestions}

- Try to provide some motivational factors to employees to increase their performance.

- Cash management in the organization has been streamlined by proper planning and control. So that optimum cash balance will be maintained

- The company should try its best to increase sales and profit.

- Comparing the current assets and current liabilities there was a increase and there is increase in current liabilities. The company should manage to improve the current assets and decrease in liabilities by increasing sales and high profit.

\section{Conclusion}

The management of working capital plays important roles to ensure the sustainability of the company in maintaining the business with an increase performance. The improper management of working capital wills results on the inefficient asset utilization and the investment for the short term will be decrease. In addition, the company wills loss a lot of opportunities to expand the business since they will suffer short-term liquidity crisis and downgrading the company's rating.

\section{REFERENCES}

[1] Madhavi K., (2014), Working Capital Management of Paper Mills, International Journal of Research in Business Management, Vol. 2, No. 3, pp. 63-71

[2] Bose, B. (2013). The impact of working capital management practices on firm's profitability. International Journal of Applied Research and Studies, 2(6), 1-15

[3] Joseph Jisha, (2014), Impact of Working Capital Management on Firm's Profitability and Liquidity: An
Empirical Study of Ashok Leyland Ltd., International Journal of Research in Commerce and Management, Vol. 5, No. 2, pp. 32-38.

[4] Asress, K. S. (2010). Determining working capital solvency level and its effect on profitability in selected Indian manufacturing firms. ICBI 2010, U n iversity of Kelaniya, Sri Lanka

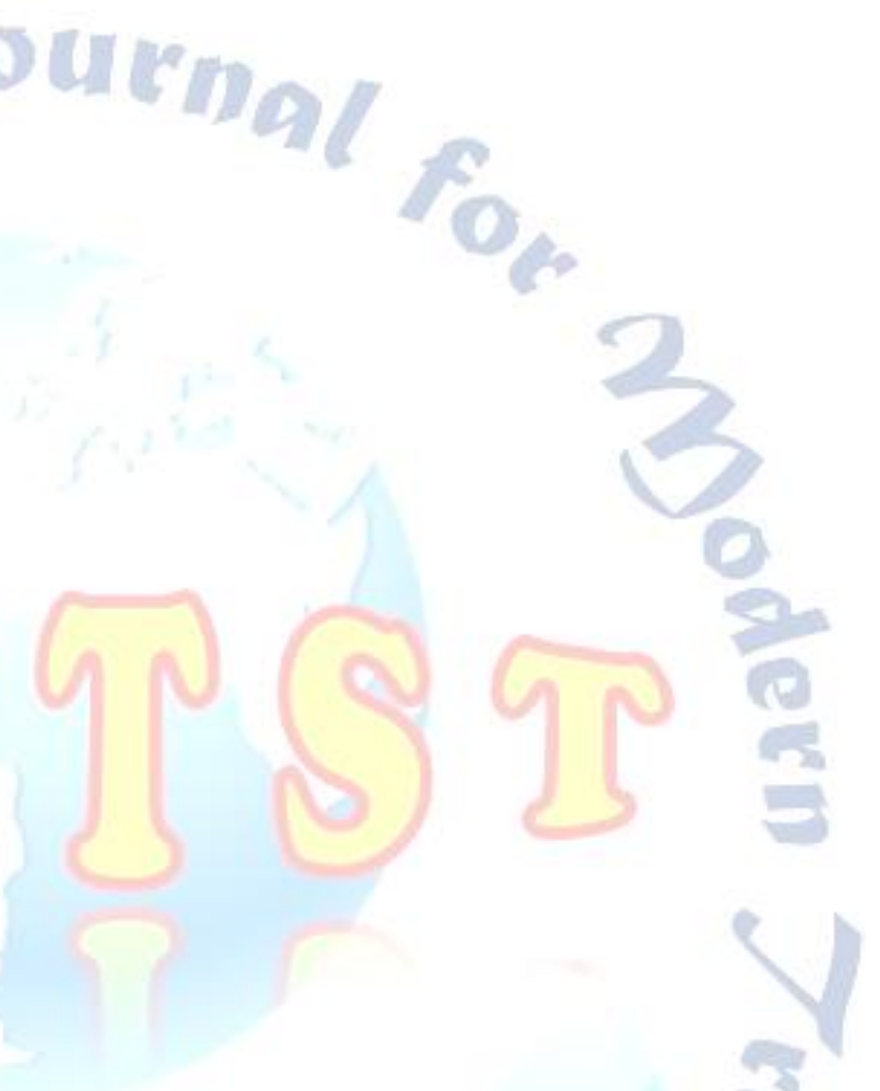

